\title{
Pelatihan Pengembangan Usaha Kecil Bidang Pangan di Kumudasmoro Selatan, Semarang
}

\author{
Ch.Trihardjanti Nugrahaningsih, Agustine Eva Maria \\ Program Studi Manajemen, Universitas Katolik Soegijapranata \\ Jl. Pawiyatan Luhur IV/1 Bendan Duwur Semarang \\ email: evamaria@unika.ac.id
}

\begin{abstract}
Abstrak: Pengabdian pada masyarakat dilakukan di Kumudasmoro Selatan dengan kalayan adalah pengusaha warung kucingan dan pengusaha jus buah. Tujuan pengabdian adalah memberikan pelatihan bagaimana mengembangkan usaha kecil yang saat ini sudah dilakukan dengan cara perbaikan dalam proses produksi. Luaran Pengabdian ini adalah mitra mampu melakukan pengembangan usaha dengan cara yang lebih baik karena menghasilkan produk yang lebih berkualitas (sehat, enak dan menarik). Metode yang digunakan adalah memberikan pelatihan pemahaman produk berkualitas dan memfasilitasi alat produksi dan pemasaran yang lebih sehat. Hasil pengabdian menunjukkan mitra memahami yang ditunjukkan dengan perubahan dalam cara memproduksi dan memasarkan.
\end{abstract}

Kata kunci: pelatihan,, usaha pangan, produk berkualitas, pemasaran berkualitas

Abstract: Community service is carried out in South Kumudasmoro with kalayan who are businessmen of food stalls and fruit juice entrepreneurs. The purpose of service is to provide training on how to develop small businesses that are currently being carried out by means of improvements in the production process. This service area is a partner capable of developing a business in a better way because it produces more quality products (healthy, tasty and attractive). The method used is to provide training in understanding quality products and facilitating healthier production and marketing tools. The results of dedication show that understanding partners are shown by changes in how to produce and market

Keywords: training, food business, quality products, quality marketing 


\section{PENDAHULUAN}

Kelemahan para pelaku usaha kecil adalah kurangnya pengetahuan yang memadai dalam mengelola usaha. Kelemahan-kelemahan usaha kecil (www.depkop.go.id, 2013) adalah intensitas perubahan usaha sering terjadi sehingga sulit untuk membangun spesialisasi atau profesionalisme usaha, Ketidakstabilan mutu produk dan adanya sifat yang cenderung ingin mencari keuntungan jangka pendek sehingga spekulatif, tiru-meniru, situasi persaingan mengarah pada persaingan tidak sehat yang dapat merugikan usaha dalam jangka panjang, manajemen keuangan belum tercatat dengan baik dan belum ada pembedaan antara konsumsi rumah tangga dengan biaya produksi, adanya keterkaitan kekerabatan yang tinggi sehingga akumulasi modal tidak dapat tercipta melainkan tersebar diantara sanak saudara, memiliki rasa kebersamaan yang menyebabkan persaingan menjadi terbatas.

Kebanyakan UMKM merupakan usaha untuk mempertahankan hidup, bukan usaha yang produktif.

Di antara para pelaku usaha skala mikro, sebanyak 80\% di antaranya adalah pelaku usaha perempuan (Soekesi, 2014). Motivasi para perempuan tersebut tidak hanya untuk menambah penghasilan keluarga dalam rangka pemenuhan kebutuhan hidupnya, namun ada juga yang melakukan usaha mandiri karena menjadi satu-satunya sumber penghasilan keluarga. Hal ini dilakukan karena tidak saja status mereka yang janda, namun ada juga yang memang suaminya tidak dapat menghasilkan uang.

Di antara para pelaku usaha skala mikro tersebut, 60\% di antaranya memilih bidang produksi pangan (makanan dan minuman). Sebagian besar alasan yang dikemukakan karena konsumen untuk bidang produk pangan memiliki repetisi pembelian yang relatif tinggi, sehingga siklus perputaran modalnya juga relatif cepat. Dengan demikian hasil yang diperoleh secara finansial dapat dipergunakan untuk memenuhi kebutuhan hidup sehari-hari. Hal ini dipersepsikan oleh para pelaku usaha relatif mudah dikelola.

Situasi dan kondisi serupa juga terjadi pada kalayan 1 dan kalayan 2. Kedua kalayan ini melakukan usaha produksi di bidang pangan dalam rangka menambah penghasilan keluarga untuk memenuhi kebutuhan hidup sehari-hari dan pendidikan anak-anaknya. Produk pangan yang dihasilkan kalayan 2 adalah nasi bungkus dan aneka gorengan dengan berbagai minuman. Kalayan 2 menyajikan produknya dengan membuat 'gerai' kaki lima semacam warung nasi kucing. Lokasinya pada 
awalnya berada di sebuah tanah lapang berjarak sekitar 50 meter dari rumahnya. Sedangkan produk pangan yang dihasilkan kalayan 1 adalah aneka minuman jus buah dan susu dalam kemasan siap konsumsi. Produk secara rutin di kantin depan Sekolah Dasar Marsudirini di Jln. Pemuda Semarang. Selain itu kalayan 1 juga melayani pesanan khusus dari para konsumen. Wilayah tempat tinggal kedua orang perempuan pelaku usaha skala mikro di bidang pangan ini di Kumudasmoro.

Berdasarkan hasil prasurvei awal teridentifikasi bahwa secara umum keberadaan usaha pangan skala mikro yang dikelola oleh kedua kalayan tersebut memiliki kelemahan sebagaimana yang dirumuskan oleh Kementrian Koperasi dan UMKM tersebut di atas. Meskipun telah dikelola lebih dari lima tahun, namun perkembangannya sangat lambat dan cenderung stagnan. Orientasi pengembangan usaha cenderung sebatas keinginan dan belum disertai dengan motivasi kuat dan kemampuan manajerial.

Kedua kalayan dalam kegiatan pengabdian ini memiliki permasalahan dalam hal pengembangan usaha. Orientasi usaha yang sebatas dalam rangka memenuhi kebutuhan hidup sehari-hari tidak dapat berdampak pada pengembangan usaha. Tidak adanya standar operasi yaitu dalam bahan baku, proses produksi, dan produk.
Ada kecenderungan fleksibilitas yang terlalu tinggi terhadap kondisi yang ada, pemilihan bahan baku lebih menekankan pada aspek harga (memilih harga bahan yang relatif rendah), tahapan dalam proses produksi ada yang tidak standar, bila ada keterbatasan waktu ada tahapan proses produksi yang tidak dilakukan, untuk kondisi tertentu produk yang dihasilkan tidak selalu standar karena pengaruh dari tidak standar-nya bahan dan proses produksi, tidak memahami konsep perencanaan kapasitas produksi, sehingga apa yang dihasilkan (produk) tidak selalu sesuai dengan apa yang direncanakan, proses produksi yang tidak mengikuti kaidah Good Manufacturing Process (GMP),keterbatasan dalam peralatan produksi sehingga dalam beberapa hal ada yang mengesampingkan faktor kebersihan.

\section{RUMUSAN MASALAH}

a. Bagaimana upaya meningkatkan motivasi berwirausaha kalayan?

b. Bagaimana upaya meningkatkan kualitas produk dan pemasaran produk?

\section{METODE}

Metode yang akan digunakan dalam kegiatan ini adalah:

\section{a. Pelatihan}

Materi pelatihan adalah motivasi berwirausaha, perencanaan kapasitas produksi, dan standar kualitas. Standar kualitas dalam hal ini dikaitkan dengan 
impelementasi GMP yaitu kebersihan dan kesehatan dalam keseluruhan. Pelatihan diberikan langsung di tempat usaha masing-masing sesuai dengan karakteristik setiap usaha. Waktu yang digunakan juga langsung dengan kegiatan usaha dilaksanakan (khususnya saat proses produksi dan display produk). Hal ini berujuan supaya materi pelatihan dapat dipahami efektif dan langsung dapat diterapkan.

\section{b. Fasilitasi peralatan usaha}

Fasilitasi perlatan usaha bertujuan untuk mendukung praktik GMP dan perencanaan kapasitas produksi. Untuk kalayan 2 (nasi bungkus) peralatan tersebut berupa peralatan masak seperti baskom untuk mencuci bahan, alat penggorengan dan tempat menyajikan produk yang tertutup (supaya tidak terkena kontaminan dari luar). Sedangkan untuk kalayan 1 (es jus dalam kemasan) yaitu berupa blender. Blender yang ada sekarang hanya satu, sehingga seringkali tidak dicuci/dibersihkan bila akan digunakan untuk melalukan proses dengan buah yang berbeda.

Adapun jadual kegiatan

a) Oktober 2015 : Prasurvey, identifikasi masalah, penyusunan proposal

b) November 2015 : Review proposal, pelatihan tahap I (membangun awareness)

c) Desember 2015 : Fasilitasi peralatan produksi

d) Januari 2016 : Pelatihan tahap II (sekaligus dalam implementasi)

e) Februari 2016 : Pelatihan tahap III (pemantauan proses dan hasil)

f) Maret 2016 : Analisis dan penyusunan draft laporan

g) April 2016 : Review draft laporan

h) Mei 2016 : laporan akhir

\section{HASIL PEMBAHASAN}

Tim pengabdian melakukan 2 metode dalam pengabdian ini yaitu pelatihan dan fasilitasi.

Tim pengabdian melakukan pengabdian dengan metode pelatihan dan fasilitasi peralatan. Penjelasan masing-masing sebagai berikut:

1. Pelatihan

Pelatihan yang dilakukan kepada kalayan meliputi 2 hal yaitu pelatihan motivasi berwirausaha dan proses produksi.

a. Pelatihan Motivasi

Motivasi adalah dorongan seseorang untuk melakukan sesuatu, motivasi menggunakan konsep yang dikembangkan oleh Mc Cleland dimana dorongan seseorang untuk melakukan sesuatu didasarkan pada 3 
kebutuhan, untuk penapaian( $N$-arch), untuk menjalin relasi ( $n$-aff), dan untuk memberikan pengaruh ( $n$ pow). Sedangkan wirausaha adalah usaha mandiri; ditambahkan oleh Widjajanto (2009; p4-7) bahwa seorang wirausaha (entrepreneur) adalah individu yang memiliki 3 hal yaitu passion(semangat untuk melakukan sesuatu), caurage (keberanian untuk mengambil keputusan dalam situasi ketidakpastian) dan leadership (kemampuan mempengaruhi orang lain) dalam mencapai tujuan bisnisnya. Oleh karena itu, pelatihan motivasi berwirausaha juga dikaitkan dengan hal tersebut. Materi Pelatihan untuk kedua kalayan disesuaikan dengan usaha kalayan.

a.1. Pelatihan motivasi bagi kalayan 1 Usaha kalayan 1 adalah jus buah dan makanan ringan. Kalayan1 berjualan di lapak yang ada di SD Marsudi Rini Semarang, dan di tempat yang sama ada 3 orang penjual makanan dan minuman yang memiliki karakteristik yan sama yaitu minuman dan makanan kecil bahkan penjual di sebelah kiri kalayan 1 memiliki jumlah jajanan yang lebih banyak dan beragam, yang artinya kalayan 1 memiliki pesaing terutama dalam minuman, maka pelatihan motivasi yang diberikan adalah dalam hal:

1. mendorong kalayan untuk memberikan penekanan image produk jus sehat melalui penggunaan gula asli, air matang dan buah yang berkualitas terutama karena pelanggan jus di SD tersebut mayoritas adalah anak-anak SD maupun penjemput adalah orang tua dari anak-anak SD, maka kualitas sehat harus tersampaikan dengan baik dan harapannya pelanggan akan membeli terus karena merasakan manfaatnya (motivasi untuk mempengaruhi pelanggan dan pencapaian)

2. Tim memotivasi juga kepada kalayan untuk tetap mempertahankan penggunaan gula asli, air matang dan buah berkualitas pada saat harga bahan bahan jus tersebut mahal(penekanan kejujuran), meskipun dengan volume yang dikurangi dan hal tersebut harus tersampaikan ke pelanggan agar pelanggan tidak merasa dibohongi sehingga tetap membeli produknya 
meski volume lebih sedikit (motivasi kejujuran untuk kebutuhan berafiliasi dan pencapaian).

3. Memotivasi untuk menjalan relasi sebanyak-banyak dengan konsumen melalui pelayanan yang ramah dan tetap menyapa pelanggan meskipun hari itu pelanggan tidak membeli produknya, jika memungkinkan membantu penjual kiri kanannya saat mereka kewalahan menangani pembeli, tujuannya adalah membangun citra positif kalayan dari pesaing maupun pelanggan (motivasi berafiliasi).

4. Salah satu hal yang menjadi kendala bagi hampir semua usaha kecil adalah memisahkan hasil penjualan untuk membeli bahan baku usaha dan untuk keperluan sehari-hari. Maka tim memberikan pelatihan untuk pencatatan untuk setiap pengeluaran dan pemasukan usaha (motivasi pencapaian).

\section{a.2.Pelatihan motivasi untuk kalayan2} Usaha kalayan2 adalah warung kucingan yang menyediakan makanan dan minuman. Makanan yang dijual adalah nasi teri, nasi sarden, nasi yam lada hitam yang dibungkus menggunakan kertas yang diberikan alas daun pisang, gorengan (mendoan, tahu, pisang, tempe gembus), sate telur, sate usus, kerupuk ikan dan makanan cemilan lainnya. Minuman yang ada adalah teh panas, es teh, jeruk panas, es jeruk, kopi, susu, milo dan minuman sachetan lainnya. Berdasarkan kondisi tersebut maka pelatihan yang diberikan pada kalayan 2 adalah :

1. Memotivasi untuk mulai memikirkan tempat usaha baru atau jika memungkinkan di pindah di rumah. Hal tersebut dilakukan dengan alasan tempat usaha kalayan 2 saat ini berada di tanah kosong milik warga yang belum ditempati oleh pemiliknya, letaknya di pinggir jalan, persisnya di perempatan jalan kampung. Status tempat usaha adalah pemanfaatan lahan kosong dan sewaktu-waktu harus pindah jika pemilik akan membangun tempat tersebut.

Oleh karena itu, perlu dipertimbangkan untuk mempersiapkan tempat usaha 
baru. Selain itu tim juga menyarankan tempat usaha barunya adalah di rumah. Kalayan 2 selama ini memasak nasi lada hitam, nasi sarden, dan nasi teri di rumah, demikian juga dengan sate telur dan sate ususnya sehingga jam 13.00 harus sudah mulai memasak dengan jumlah yang terbatas (maksimal 20 bungkus) baru dibawa ke warung nasi kucing yang letaknya kurang lebih 100 m dari rumah, kalau nasi bungkus tersebut habis dan masih ada permintaan dari pembeli , beliau tidak bisa menambah lagi karena tidak mungkin memasak lagi di rumah karena harus menunggui warung. Diharapkan kalau tempat usaha di rumah maka kalayan bisa memenuhi sewaktu-waktu permintaan tambahan.

Selain itu, dengan tempat usaha di rumah, kalayan tidak perlu membawa bolak-balik peralatan masaknya seperti kompor gas, panci, wajan, gas, sotel dan juga gelas, piring, sendok,termos, bahan bahan yang digoreng seperti tahu, tempe, dan pisang. Kalayan juga tidak perlu tiap hari bawa gerobak, kursi, meja bolak balik. Kebetulan di rumah kalayan ada tempat meskipun tidak terlalu luas namun bisa digunakan dan pelanggan sudah banyak .

2. Memotivasi kalayan 2 untuk menjual produk dengan peralatan dan perlengkapan yang bersih dan tertutup agar terhindar dari debu atau lalat. Awalnya tim memberikan pemahaman pentingnya produk yang bersih dan sehat. Pelatihan ini dilakukan dengan tujuan untuk menanamkan pada kalayan 2 bahwa berjualan sebaiknya dapat memberikan dampak positif tidak hanya untuk penjual namun juga pembeli atau pelanggan. Penjual tetap memperoleh keuntungan tanpa harus merugikan pembeli/pelanggan meski dampak kerugiannya tidak seara langsung di rasakan oleh pembeli/pelanggan (motivasi berafiliasi).

Tim memotivasi untuk selalu menjaga kebersihan tempat usaha dengan memberikan 
peralatan sapu lidi, sehingga tempat usaha tetap terlihat bersih. Tim juga menyarankan kalayan untuk menggunakan perlengkapan yang bersih dan tertutup maka tim memberikan tempat makanan yang tertutup untuk makanan yang tidak berbungkus seperti gorengan, sate telur dan sate usus. Tim menyarankan juga untuk menggunakan daun pisang sebagai alas tempat makanan yang masih panas agar tidak langsung berkontaminasi dengan plastik. Semua itu dilakukan untuk menjaga makanan tersebut tetap sehat saat dinikmati oleh pembeli (motivasi berafiliasi dan pencapaian).

Tim menyampaikan kepada kalayan bahwa ada hubungan antara manfaat sehat yang diperoleh pembeli/pelanggan dengan keuntungan penjualan, dengan kalayan menyajikan tempat usaha yang bersih maka akan membuat pembeli nyaman saat makan dan minum meski di warung kucingan dan itu akan membuat pembeli datang lagi untuk membeli dan itu berarti keuntungan bagi kalayan. Jika kalayan menjual produk yang enak, bersih dan sehat karena disajikan dengan tempat tertutup terhindar dari debu dan lalat, maka pembeli akan memiliki persepsi yang positif "makan di warung kucing enak, bersih, sehat" dan itu akan membuat pembeli datang lagi untuk membeli dan itu berarti keuntungan untuk kalayan (motiasi berafialiasi, memberikan pengaruh melalui image positif dan pencapaian) .

3. Pelatihan untuk menekankan pentingnya salam, senyum, sapa pada pembeli yang datang. Salam senyum dan sapa merupakan pelayanan yang harus diberikan kepada siapa saja yang datang agar memberikan rasa nyaman pada pembeli (motivasi berafiliasi) ini dapat menjadi daya tarik pembeli untuk datang(motivasi mempengaruhi), karena ada salam, senyum, sapa, makanan dan minuman bersih, sehat dan enak.

b. Pelatihan Perencanaan Kapasitas Produksi 
Pemahaman terhadap kapasitas produksi bagi usaha kecil penting untuk mengetahui kemampuan dalam menghasilkan produk yang disesuaikan dengan daya serap pasar. Manajemen permintaan dari kedua kalayan yaitu kalayan 1 dan kalayan 2 berdasarkan peramalan permintaan dan pesanan. Namun pesanan tidak selalu rutin pada periode waktu tertentu, hanya berupa pesanan dari konsumen yang kebetulan sedang ada keperluan (hajatan) dengan jumlah pesanan tidak lebih dari 100 unit produk. Mencermati bahwa usaha yang dikelola masuk ke dalam kategori usaha mikro dengan keterbatasan pengetahuan manajemen usaha, maka pelatihan dilakukan secara implisit persuasif.

Usaha yang dikelola kalayan 1 berupa usaha minuman dingin dalam kemasan (es jus buah segar, susu, serta es mambo). Sedangkan Ibu kalayan 2 berupa usaha nasi kucing, aneka lauk (terutama aneka gorengan) dan minuman hangat dan dingin. Kedua usaha memiliki karakteristik berbeda terkait dengan perencanaan kapasitas. Dengan demikian implementasi konsep perencanaan kapasitas dalam pelatihan juga disesuaikan.

b.1. Usaha minuman dingin kalayan 1 Produk minuman dingin yang dihasilkan ibu kalayan 1 dijual di lapak depan SD Marsudirini (jalan Pemuda Semarang). Di tempat inilah pusat penjualan seluruh produk minuman ibu kalayan 1 dari hari Senin sampai Sabtu. Sedangkan pesanan tertentu tidak selalu ada, sehingga relatif mudah untuk disesuaikan. Penjulan juga dilakukan bila ada ada even tertentu seperti bazar dan pameran yang memungkinkan. Memungkinkan dalam hal ini adalah lokasi relatif terjangkau dan ada yang menunggu stand.

Karakteristik lain adalah umur simpan produk minuman tersebut relatif pendek. Meskipun disimpan dalam lemari pendingin, tetapi untuk menjaga kualitas konten-nya (terutama rasa) maka hanya dapat disimpan tidak lebih dari 24 jam. Ketersediaan jenis buah untuk produk minuman dingin tersebut juga berdasar musim. Jenis buah yang selalu tersedia adalah jeruk. Sehingga jus jeruk selalu dapat disediakan setiap hari. Demikian juga untuk susu (coklat), karena bahan 
bakunya selalu tersedia di toko pengecer.

Untuk persediaan bahan baku

Dengan demikian yang perlu diperhatikan adalah melakukan manajemen permintaan. Untuk permintaan yang bersifat rutin (penjualan di SD Marsudirini) harus memperhatikan kinerja penjualan periode sebelumnya untuk mengidentifikasi jumlah dan jenis buah (berdasar musim) yang diminati. Oleh karenanya informasi penting yang harus selalu diketahui kalayan 1 adalah hari kerja sekolah serta kegiatan yang menentukan hari dan jam operasional sekolah. Hal ini penting karena konsumen utama adalah siswa dan para pengantar/penjemput siswa. Untuk permintaan berdasar pesanan, disarankan agar bu kalayan 1 menginformasikan kepada para pelanggan untuk memesan setidaknya 1,5 hari sebelumnya. Lead time ini perlu dipertimbangkan mengingat ibu kalayan 1 berbelanja bahan baku buah-buahan pada sore hari untuk kemudian dilakukan proses produksi dan dijual atau dikirim kepada pelanggan keesokan harinya. lainnya yaitu berupa gula dapat dikelola dengan relatif mudah karena memiliki umur simpan yang relatif lama dan tersedia di pedagang retail. Yang perlu dikelola adalah cup dan seal penutup, karena pernah mengalami stockout dan retail yang menjadi langganannya sedang tutup. Oleh karenanya disarankan untuk mencari pemasok cadangan. Melalui proses survei singkat sudah teridentifikasi retail yang produk cup dan seal-nya memenuhi kriteria jenis dan ukuran yang sesuai.

Untuk fasilitas produksi utama berupa blender, dapat dikatakan lebih dari cukup. Pada awalnya memiliki 2 blender masingmasing dengan kapasitas 2,5 liter. Kedua blender tersebut dipisahkan untuk membuat minuman jenis susu dan buah agar mencegah kontaminasi rasa. Namun karena produksi minuman buah 3 kali lebih banyak dibanding susu, maka dengan program fasilitasi peralatan produksi ditambahkan 
satu buah blender. Dengan demikian kapasitas produksi menjadi 2 kali lebih banyak untuk proses produksi minuman buah.

Dengan adanya penambahan satu buah blender ini, maka proses produksi relatif menjadi lebih cepat $50 \%$ untuk pembuatan minuman buah. Peningkatan kapasitas produksi dapat memberikan efisiensi proses produksi, sehingga bila ada peningkatan jumlah produksi (terutama karena pesanan), lebih cepat untuk direspon dalam melakukan kegiatan proses produksi.

\section{b.2. Usaha nasi kucing kalayan 2}

Usaha yang dimiliki kalayan 2 memiliki karakteristik yang berbeda. Produk yang relatif beragam jenisnya dengan jumlah produksi masing-masing yang relatif sedikit memerlukan pemahaman pengendalian produksi dengan tipe by order. Dengan demikian diperlukan pemahaman menentukan prioritas proses produksi untuk produk yang memiliki nilai jual relatif tinggi dan membutukan waktu proses lebih lama.

Berdasarkan identifikasi jenis dan tahap proses produksi untuk semua jenis produk, maka produk utama berupa nasi kucing dan lauknya menjadi priorits untuk diproses terlebih dahulu. Jumlah produksi yang hanya 40 bungkus per hari sebenarnya masih dapat ditambah mengingat potensi pasar sangat tinggi. Sangat tinggi dalam konteks ini karena seluruh nasi kucing yang dihasilkan habis terjual dalam waktu maksimal 5 jam dari dimulainya waktu penjualan.

Keterbatasan seluruh fasilitas produksi yang dimiliki serta tenaga kerja yang hanya satu orang, menyebabkan proses produksi harus dilakukan 2 kali untuk meningkatkan jumlah produksi. Apabila ini dilakukan maka akan tersita waktu lebih lama, sehingga waktu penjualan akan terlamat (mundur sekitar dua jam dari waktu yang biasanya). Oleh karenanya dalam pelatihan diberikan pemahaman untuk mengoptimalkan produk yang lain agar penjualan juga optimal.

Optimasi kapasitas produksi untuk mensubstitusi penjualan nasi 
kucing dilakukan untuk produk aneka gorengan dan minuman panas / hangat. Fasilitasi temapt air matang dan peralatan untuk proses produksi aneka gorengan sangat mendukung upaya ini.

Dalam prakteknya, persiapan bahan untuk aneka minuman hangat dan aneka gorengan sudah disiapkan dalam bentuk bahan setengah jadi. Sehingga pada saat penjualan baru dilakukan tahap akhir proses produksi yang memungkinkan produk dapat disajikan fresh kepada konsumen. Optimasi produk minuman dan aneka gorengan ini terbukti dapat mensubstitusi potensi penjualan produk nasi kucing, namun tidak menambah waktu persiapan proses produksi yang signifikan. Fasilitasi berupa tempat display produk aneka gorengan dapat meningkatkan kebersihan dalam penyajian, karena tempat display tersebut memiliki tutup yang relatif mudah dibuka dan ditutup.

Optimasi produk aneka gorengan yang juga mengoptimalkan kapasitas produksi yang ada didukung dengan kemudahan ketersediaan seluruh bahan baku. Karena pada dasarnya seluruh bahan baku yang diperlukan untuk produk yang dihasilkan dan dijual oleh kalayan 2 tersedia di banyak pedagang pengecer (pasar). Karakteristik produk juga tidak spesifik, sehingga dapat diperoleh di banyak pedangang pengecer. Namun demikian dalam pelatihan juga disampaikan perlunya menjaga hubungan baik kepada pedagang pengecer tertentu (sebagai pemasok) untuk mendapatkan layanan yang lebih baik.

Bentuk layanan tersebut merupakan perwujudan dari implementasi variabel dalam metode evaluasi pemasok. Bentuk layanan dari pemasok yang dapat diterima oleh ibu Purgiyanti bila menjaga hubungan baik dengan pemasok adalah adanya retur bila produk tidak sesuai dengan yang dipesan. Selain itu juga fasilitasi pembayaran yang tidak harus semuanya dibayar secara tunai.

2. Fasilitasi Peralatan

Fasilitasi peralatan diberikan dengan tujuan memotivasi mitra untuk tetap berwirausaha dengan konsep "hijau" (menggunakan peralatan yang menekankan pada kebersihan).

Peralatan yang diberikan untuk mitra I 
(warung kucingan) adalah

a. Wadah makanan tertutup

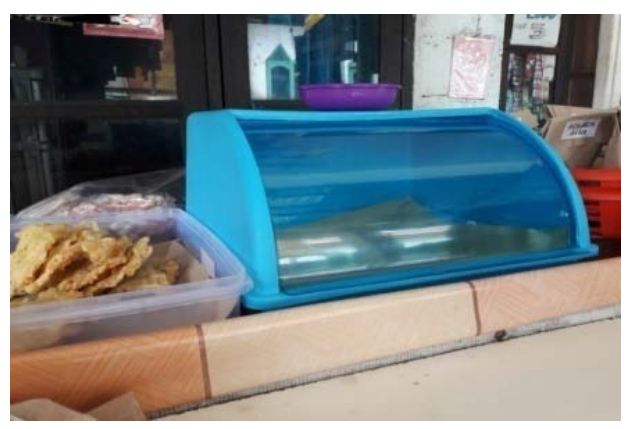

Wadah putih plastik di bawahnya diberikan alas daun pisang bertujuan untuk menampung gorengan yang masih panas kemudian diletakkan di wadah biru yang juga beralaskan daun agar makanan tidak berkontaminasi dengan plastik, sehingga makanan lebih sehat dinikmati. Wadah biru dengan tutup transparan berguna untuk menampung makanan yang tidak ada bungkusnya agar terhindar dari lalat dan debu.

b. Termos besar

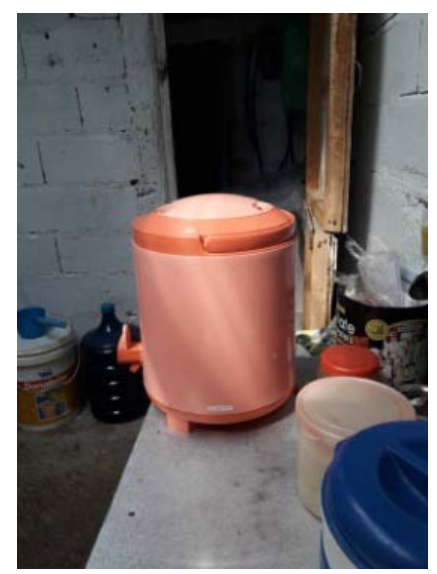

Termos ini menjadi tempat teh agar tetap tersaji panas tanpa harus menambahkan air panas sehingga mempercepat pelayanan kalayan kepada konsumen, dan lebih sehat karena disimpan dalam termos bukan di teko plastik(sebelumnya menggunakan teko plastik).

c. Blender

Kalayan sebelumnya memiliki 2 buah blender namun satunya rusak, maka tinggal satu blender yang digunakan untuk membuat jus buah dan membuat susu (pop ice), dan penggunaan blender untuk keduanya dapat mempengaruhi kualitas keaslian rasa dari buah (meskipun sudah dicuci bersih) dan kuantitas yang lebih sedikit, maka tim berinisiatif untuk memberikan blender kepada kalayan untuk membantu meningkatkan kualitas maupun kuantitas produk jualan sehingga jus buah tetap dapat dibuat bersamaan waktunya dengan susu namun dengan blender yng berbeda dan jumlah jus buah dan susu dapat dibuat lebih banyak .

d. Sapu lidi

Sapu lidi diberikan untuk menjadi alat kebersihan tempat usaha sehingga selalu terlihat bersih.

e. Piring lidi

Piring lidi diberikan untuk membantu ibu Purgianti untuk tempat makanan yang disajikan (misal gorengan yang dinikmati pembeli agar tidak pecah tu 
mencuci piring terlalu banyak.

\section{f. Celemek}

Celemek diberikan dengan tujuan saat kalayan menggoreng atau membuat jus, celemek bisa melindungi baju kalayan sehingga saat harus melayani pembeli akan terlihat tetap bersih.

Berdasarkan hal tersebut terkait pelatihan dan fasilitasi, tim berharap mampu meningkatkan hasil bagi kedua pelaku usaha, meskipun tidak dalam jangka pendek. Hasil sementara (berdasarkan pengamatan dan wawancara pada tanggal 6 Januari 2017), kedua kalayan sudah menggunakan alat-alat yang difasilitasi oleh tim. Kalayan 1 sudah menjual produknya lebih banyak karena ada tambahan blender dan kalayan 2 sudah memindahkan tempat usahanya ke tempat tinggalnya karena tempat usaha lamanya sudah diminta kembali oleh pemilik tanah, saat diwawancara kalayan 2 menyampaikan bahwa menjadi lebih baik memang di tempat tinggalnya karena kalayan tidak perlu lagi bolak-balik bawa peralatan, gerobak dan lainnya, semua peralatan tetap di tempat, gerobak tinggal ditutup menggunakan mmt(dulu harus menurunkan semua barang dagangan kemudian membereskan semua alat dan mengangkat alat alat dari warung ke rumahnya lalu mendorong gerobak, jadi lebih capai). Saat ini kalayan dapat membuka dan menutup warungnya lebih fleksibel, dapat sewaktu-waktu menambah jumlah nasi kucing, dan dapat memanfaatkan waktu saat pembeli belum datang untuk memasak atau kegiatan rumah tangga lagi. Fasilitas yang diberikan oleh tim seperti tempat makanan yang tertutup, termos, piring juga sudah digunakan kalayan.

\section{SIMPULAN}

Kalayan sudah memahami hasil dari pelatihan yang diberikan baik dalam motivasi maupun proses produksi dan ada beberapa yang sudah terlaksana, sedangkan beberapa lainnya terutama bagaimana citra positif kalayan diukur hanya dapat dilihat dalam jangka yang lebih lama (kurang lebih satu tahun).

Fasilitas juga sudah dipergunakan oleh kalayan untuk meningkatkan produksi maupun penjualannya.

\section{DAFTAR PUSTAKA}

Render, Barry dan Jay Heizer, (2010), Manajemen Operasi, Salemba Empat, Jakarta

Robbins, S.P, Judge. (2008). Perilaku Organisasi. Salemba Empat. Jakarta

Widjayanto,B. (2009). Cara aman memulai bisnis. Grasindo. Jakarta.

Yamit, Zulian (2008). Manajemen Produksi dan Operasi, Ekonisia UII, Yogyakarta www.depkop.go.id, 2013, diakses 24 April 2013 